\title{
Spinal procaine with and without epinephrine and its relation to transient radicular irritation
}

Lyne Bergeron $\mathrm{MD}$,

Michel Girard MD MHPE FRCPC,

Pierre Drolet MD FRCPC,

Yvan Grenier MD FRCPC,

Hong Hanh Le Truong MD,

Carl Boucher MD

Purpose: To document the clinical characteristics of procaine with or without the addition of epinephrine.

Methods: In this randomized, prospective, double blind study, 62 patients received spinal anesthesia with 100 $\mathrm{mg}$ procaine and either $0.3 \mathrm{mg}$ epinephrine (EPI group) or $0.3 \mathrm{ml} \mathrm{NaCl} 0.9 \%$ (SALINE group). Sensory anesthesia to needle prick was evaluated q I $\mathrm{min}$ for $10 \mathrm{~min}, \mathrm{q} 3 \mathrm{~min}$ for $33 \mathrm{~min}$ and q $5 \mathrm{~min}$ until regression to $L_{4}$. Motor block was assessed with the Bromage scale. Patients were questioned, by telephone, for transient radicular irritation (TRI) $48 \mathrm{hr}$ later.

Results: Time to reach highest sensory level and number of segments blocked showed no difference. Mean time for regression of the sensory level to $T_{10}$ was longer in EPI $(83 \pm 23$ vs $66 \pm 20 \mathrm{~min}, P<0.01)$. Time to recuperate to full flexion of knees and feet (Bromage 4) was longer in EPI (126 \pm 37 vs $100 \pm 30 \mathrm{~min}, P<0.01)$. Patients in EPI received more ephedrine. Eighteen patients had nausea (I5 EPI $B$ SALINE, $P<0.0015$ ). One patient had TRI, incidence: $1.67 \%, 95 \% \mathrm{Cl}(<1 \%-9 \%)$.

Conclusion: Spinal procaine is appropriate for surgery of short duration. Epinephrine prolongs sensory and motor blocks by $25 \%$. However, it is associated with a high incidence of nausea.

Objectif : Établir les caractéristiques cliniques de la procaïne employée seule ou avec l'ajout d'adrénaline.

Méthode : Dans cette étude prospective, à double insu et à distribution aléatoire des sujets, on a procédé à une rachianesthésie avec $100 \mathrm{mg}$ de procaïne et $0,3 \mathrm{mg}$ d'adrénaline I: 1000 (groupe EPI) ou 0,3 $\mathrm{ml} \mathrm{de} \mathrm{NaCl} 0,9 \%$ (groupe SALIN). Le bloc sensitif a été évalué à l'aide d'une aiguille q I min pour $10 \mathrm{~min}$, q $3 \mathrm{~min}$ pour $33 \mathrm{~min}$ et q 5 min jusqu'à la régression du bloc à $L_{4}$. Le bloc moteur à été évalué à l'aide de l'échelle de Bromage. On a procédé à un questionnaire téléphonique, 48 heures après l'intervention, pour évaluer la présence d'irritation radiculaire transitoire (IRT).

Résultats : Le délai pour atteindre le niveau sensitif maximum et le nombre de segments bloqués sont comparables. La durée moyenne de régression du bloc sensitif à $T_{10}$ a été supérieure dans le groupe EPI $(83 \pm 23$ vs $66 \pm 20 \mathrm{~min}, P<0,01)$. Le temps nécessaire pour une récupération complète du bloc moteur a été plus long dans le groupe EPI $(126 \pm 37$ vs $100 \pm 30 \mathrm{~min}, P<0,01)$. Les patients du groupe EPI ont reçu plus d'éphédrine. Dix-huit sujets ont ressenti des nausées ( 15 EPI $/ 3$ SALIN, $P<0,0015)$. Un cas d'IRT a été identifié, incidence: $1,67 \%$, IC $95 \%(<1 \%-9 \%)$.

Conclusion : La procaiine intrarachidienne est adéquate pour les interventions chirurgicales de courte durée. L'épinéphrine prolonge les blocs sensitif et moteur d'environ $25 \%$. Cependant, son utilisation est associée à une incidence accrue de nausées.

From the Département d'anesthésic-réanimation, Hôpital Maisonneuve-Rosemont and Université de Montréal, 5415 boul. L'Assomprion, Montréal, Québec, HIT 2M4 Canada.

Address correspondence to: Docteur Michel Girard, Phone: 514-252-3426; Fax: 514-252-3542; E-mail: girardmi@videotron.ca

Presented at the June 1998 Canadian Anesthesiologists' Society meeting.

Accepted for Publication, June 1, 1999 
ROCAINE, a short-duration local anesthetic, has been known since 1905. Surprisingly, the precise characteristics of a spinal procaine block, with or without epinephrine, have never been documented in a randomized double blind manner.

Until recently, lidocaine seemed to be the ideal medication for ambulatory spinal anesthesia. However, its association with transient radicular irritation (TRI) ${ }^{1-4}$ has been responsible for its dismissal by many anesthesiologists. The only account of TRI associated to spinal procaine comes from a retrospective study reporting a $15 \%$ incidence in 17 patients. $^{5}$

In this study, our primary goal was to define the characteristics of spinal procaine, with and without epinephrine. Our secondary goal, was to evaluate its association with TRI.

\section{Methods}

After Institutional Review Board approval and written informed consent, 62 patients, ASA I and II, aged 18 to $65 \mathrm{yr}$, scheduled for surgery of short duration under spinal anesthesia, were studied. Exclusion criteria were allergy to local anesthetics or to $p$-amino benzoic acid, neurological, coagulation or cholinesterase anomalies and a body mass index $>$ to 28 .

Patients were divided into two groups in a randomized double blind prospective manner. Patients in the SALINE group $(n=31)$ received $1 \mathrm{ml}$ procaine $10 \%$, plus $0.3 \mathrm{ml}$ saline $0.9 \%$, patients in the EPI group $(\mathrm{n}=31)$ received $1 \mathrm{ml}$ procaine $10 \%$, plus $0.3 \mathrm{ml}$ of 1:1000 epinephrine. Routine monitors were used (Datex AS3). Patients received 1 or $2 \mathrm{mg}$ midazolam iv. All were pre-hydrated $\left(10 \mathrm{ml} \cdot \mathrm{kg}^{-1}\right.$, saline $0.9 \%$ ip), then a blood pressure (BP) measurement was taken and used as baseline value. With the patient sitting, a midline lumbar puncture was performed with a 27-G Whitacre needle at the L3-L4 space. One ml CSF was drawn to dilute the procaine to $5 \%$. The end of the injection was T0. Sensory anesthesia was evaluated with a $26-\mathrm{G}$ needle at one minute intervals for $10 \mathrm{~min}$, three minute intervals for $33 \mathrm{~min}$ and then five minute intervals until regression to T10. Once in the PACU, motor blockade was assessed with the Bromage scale.

The BP was measured simultaneously with sensory levels. Hypotension was defined as a decrease in systolic BP < $90 \mathrm{mmHg}$ or $20 \%$ < baseline value. It was treated with 5-10 mg ephedrine iv. Pain during surgery was treated with $50 \mu \mathrm{g}$ fentanyl $i v$ and nausea with $10 \mathrm{mg}$ metoclopramide $i v$. Pain in the PACU was treated with meperidine $i v(10 \mathrm{mg})$.

On the second postoperative day, patients were asked by telephone ${ }^{3,6}$ if they suffered from backache. If so, they were asked if it radiated into the buttocks or legs. Care was taken to differentiate TRI from pain related to spinal puncture. Onset, duration and treatment were noted. Pain was assessed with a verbal rating scale (0 to 10). TRI was defined as a moderate or severe bilateral pain starting at the back or buttocks and radiating to the thighs and calves. The pain had to begin < $24 \mathrm{hr}$ after anesthesia and last $>24 \mathrm{hr}^{1,7}$ All data/decisions were gathered/made by a blinded physician.

Demographic data, time to highest sensory level and regression to $\mathrm{T}_{10}$, fentanyl doses, incidence of nausea and ephedrine administration were compared with Student's $t$ test or Fisher's exact test. Blocked segments, at each interval, were compared with Mann-Whitney U test with Bonferroni correction. Repeated BP measurements were analyzed with two-way analysis of variance. Motor block regression was analyzed with KaplanMeier curves and log-rank test. Results are expressed as mean $\pm S D$ unless stated otherwise.

\section{Results}

There was no difference between groups with regard to demographic data, duration or type of surgery (Table I). Time to highest sensory level and maximum number of segments blocked showed no difference between the groups. Time for sensory regression to $\mathrm{T}_{10}$ and for regression of the motor block were shorter in group SALINE (Table II).

TABLE I Demographic data and type of surgery

\begin{tabular}{lll}
\hline & $\begin{array}{l}\text { Group SALINE } \\
(n=30)\end{array}$ & $\begin{array}{l}\text { Group EPI } \\
(n=30)\end{array}$ \\
\hline Age $(\mathrm{yr})$ & $39 \pm 12$ & $39 \pm 14$ \\
Weight $(\mathrm{kg})$ & $65 \pm 12$ & $69 \pm 11$ \\
Height $(\mathrm{cm})$ & $168 \pm 7$ & $170 \pm 10$ \\
Sex $(\mathrm{M} / \mathrm{F})$ & $17 / 13$ & $20 / 10$ \\
Type of surgery $(\mathrm{n})^{*}$ & $2 / 16 / 12$ & $1 / 10 / 19$ \\
\hline
\end{tabular}

Values are $n$ or mean $\pm \mathrm{SD}$, *urology/orthopedic surgery/general surgery

TABLE II Characteristics of blocks

\begin{tabular}{lll}
\hline & $\begin{array}{l}\text { Group SALINE } \\
(n=30)\end{array}$ & $\begin{array}{l}\text { Group EPI } \\
(n=30)\end{array}$ \\
\hline $\begin{array}{l}\text { Time from injection to highest } \\
\text { sensory level (min) }\end{array}$ & $18.5 \pm 8.4$ & $15.7 \pm 6.8$ \\
$\begin{array}{l}\text { Maximum number of blocked } \\
\text { segments above L4 (n) }\end{array}$ & $12(8-15) \dagger$ & $13(8-16) \dagger$ \\
$\begin{array}{l}\text { Time for sensory regression } \\
\text { to T 10 (min) }\end{array}$ & $66 \pm 20$ & $83 \pm 23^{*}$ \\
$\begin{array}{l}\text { Time for regression of motor } \\
\text { block to Bromage 4 (min) }\end{array}$ & $100 \pm 30$ & $126 \pm 37^{*}$ \\
\hline
\end{tabular}

Values are mean \pm SD except $\dagger$ values are median (range), ${ }^{*} P<0.01$ 


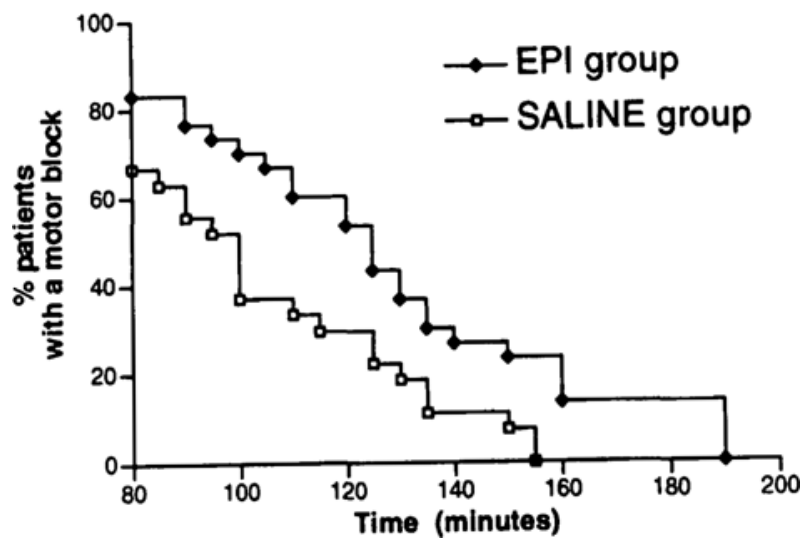

FIGURE 1 Recovery from motor block, Kaplan-Meier curves, log-rank test: $P<0.05$

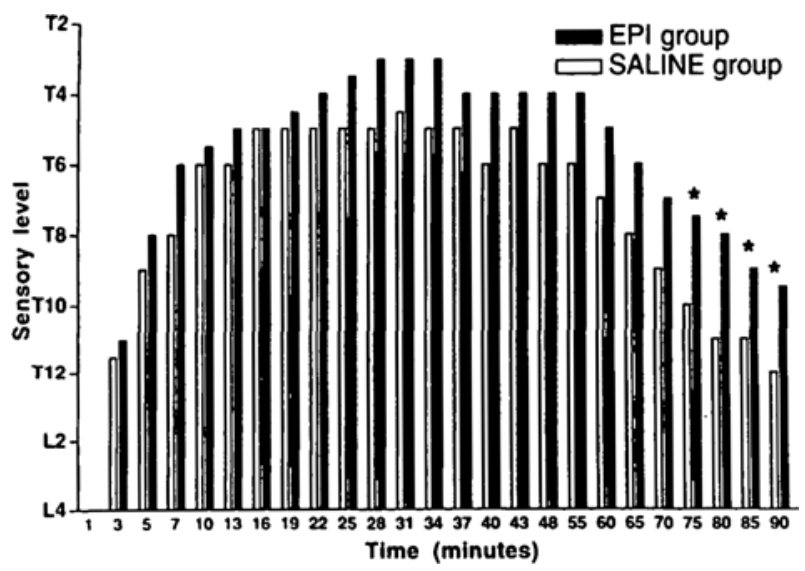

FIGURE 2 Sensory level as a function of time, Mann-Whitney $\mathrm{U}$ test for each interval with Bonferroni correction for multiple comparisons: ${ }^{*} P<0.05$

Figure 1 shows that residual motor block was greater in group EPI. After $55 \mathrm{~min}$ following injection, sensory levels were lower in the SALINE group (Figure 2).

Doses of fentanyl ( $50 \mu \mathrm{g}$, three patients/group, 100 $\mu \mathrm{g}$, one patient/group) or midazolam (SALINE: 1.85 $\pm 1.02 \mathrm{mg}$, EPI: $2.10 \pm 0.98 \mathrm{mg}$ ) administered showed no difference. Although systolic BP were similar for each interval, group EPI received more ephedrine (4.8 $\pm 8.2 \mathrm{mg})$ than group SALINE $(1.5 \pm 3.5 \mathrm{mg})$. More patients in group EPI had nausea (EPI: 15 patients, SALINE: 3 patients, $P<0.0015$ ). Three patients received meperidine ip in PACU, all in group SALINE.
Two patients had inadequate surgical anesthesia, one in each group. They both needed general anesthesia and were excluded from the final data analysis.

One patient, belonging to group EPI, had TRI $1.6 \%(95 \% \mathrm{CI}$ : $<1-9 \%)$.

\section{Discussion}

The short duration of action of procaine may be insufficient for a number of interventions. The addition of epinephrine broadens its usefulness. One publication in 1950, reported that epinephrine prolongs the action of spinal procaine by $65 \% .^{8}$ In this study, sensory and motor blocks were prolonged by $25 \%$, without altering onset or maximum spread.

Spinal procaine with spinal epinephrine, could be associated with more nausea than other local anesthetics. ${ }^{9}$ Although episodes of hypotension could be responsible for the higher incidence of nausea in group EPI, there was no difference in mean BP between our two groups for any of the time interval studied. In group SALINE, three patients had nausea $(3 / 30,10 \%)$, that is comparable with other local anesthetics.

In each of the inadequate blocks, surgery outlasted the duration of procaine (22 and $55 \mathrm{~min}$ ). Fentanyl was given for pain related to prompt surgery after the spinal technique.

One patient had TRI. He had a TURP in a low lithotomy position. The incidence of TRI varies from $10 \%$ to $40 \%$ after spinal lidocaine.$^{3,4,10}$ Lithotomy position could be a predisposing factor for TRI. ${ }^{3}$ The incidence of TRI, in this study, is $1.6 \%$ (CI: $<1-9 \%$ ).

\section{Conclusion}

Spinal procaine is appropriate for surgery of short duration. Adding epinephrine prolongs sensory and motor blocks by approximately $25 \%$, without modifying onset time or maximum spread. However, the use of epinephrine is associated with an increased incidence of nausea. The incidence of TRI we have encountered makes procaine a likely candidate for ambulatory anesthesia.

\section{Acknowledgment}

The authors wish to thank Mrs. Christiane Côté BSc for her assistance in the data collecting for this work.

\section{References}

1 Pinczower GR, Chadwick HS, Woodland R, Lowmiller $M$. Bilateral leg pain following lidocaine spinal anaesthesia. Can J Anaesth 1995; 42: 217-20.

2 Tarkkila $P$, Hubtala J, Tuotninen $M$. Transient radicular irritation after spinal anaesthesia with hyperbaric $5 \%$ lignocaine. Br J Anaesth 1995; 74: 328-9. 
3 Pollock JE, Neal JM, Stephenson CA, Wiley CE.

Prospective study of the incidence of transient radicular irritation in patients undergoing spinal anesthesia.

Anesthesiology 1996; 84: 1361-7.

4 Hampl KF, Schneider MC, Pargger H, Gut J, Drewe J, Drasner $K$. A similar incidence of transient neurologic symptoms after spinal anesthesia with $2 \%$ and $5 \%$ lidocaine. Anesth Analg 1996; 83: 1051-4.

5 Pollock JE, Mulroy MF, Stephenson C. Spinal anesthetics and the incidence of transient radicular irritation. Anesthesiology 1994; 81: A1029.

6 Liguori GA, Zayas VM, Chisholm MF. Transient neurologic symptoms after spinal anesthesia with mepivacaine and lidocaine. Anesthesiology 1998; 88: 619-23.

7 Tarkila $P$, Hubtala J, Tuominen $M$, Lindgren $L$. Transient radicular irritation after bupivacaine spinal anesthesia. Reg Anesth 1996; 21: 26-9.

8 Kretchmer HE, Adriani J. A comparative study of certain vasoconstrictors on the duration of spinal anesthesia with procaine. South Med J 1950; 43: 771-3.

9 Carpenter RL, Caplan RA, Brown DL, Stepbenson C, $W u R$. Incidence and risk factors for side effects of spinal anesthesia. Anesthesiology 1992; 76: 906-16.

10 Hampl KF, Schneider MC, Ummenhofer W, Drewe J. Transient neurologic symptoms after spinal anesthesia. Anesth Analg 1995; 81: 1148-53. 